\title{
Understanding the Vegetable Contamination Process with Parasites from Wastewater Irrigation and Its Impact on Human Health in Hidalgo, Mexico
}

\author{
Saúl Montero-Aguirre ${ }^{1}$, Iourii Nikolskii-Gavrilov ${ }^{1}$, Cesáreo Landeros-Sánchez ${ }^{2}$, Oscar Luis Palacios-Vélez ${ }^{1}$, \\ L. Traversoni-Domínguez ${ }^{3} \&$ Juan Manuel Hernández-Pérez ${ }^{2}$ \\ ${ }^{1}$ Colegio de Postgraduados Campus Montecillo, Carretera México-Texcoco, Ciudad de Montecillo, Municipio \\ de Texcoco, Estado, México \\ ${ }^{2}$ Colegio de Postgraduados Campus Veracruz, Carretera Federal Xalapa-Veracruz, vía Paso de Ovejas, Entre \\ Puente Jula y Paso San Juan, Tepetates, Manlio F. Altamirano, Veracruz, México \\ ${ }^{3}$ Consulado de Uruguay en México, Ciudad, México \\ Correspondence: Cesáreo Landeros-Sánchez, Colegio de Postgraduados Campus Veracruz, Km 88.5 Carretera \\ Federal Xalapa-Veracruz, vía Paso de Ovejas, Entre Puente Jula y Paso San Juan, Tepetates, Manlio F. \\ Altamirano, Veracruz, C.P. 91690, México. E-mail: clandero@colpos.mx
}

$\begin{aligned} & \text { Received: February 13, } 2016 \quad \text { Accepted: March 16, } 2016 \quad \text { Online Published: April 15, } 2016 \\ & \text { doi:10.5539/jas.v8n5p42 }\end{aligned}$ URL: http://dx.doi.org/10.5539/jas.v8n5p42

\begin{abstract}
The use of untreated municipal wastewaters for irrigating agricultural crops negatively affects human health. Thus, the sewage effluent from the city of Pachuca, in the state of Hidalgo, Mexico, used for agricultural purposes was the most important reason to undertake this research work, whose main objective was to understand the process that involves its current use as irrigation water, and the potential harm to human health because the raw vegetables produced using this irrigation scheme are being consumed by the general public. The content of fecal coliforms and helminth eggs in wastewaters were determined and the level of parasitological contamination of vegetables and the potential number of people affected was estimated due to the consumption of raw produce without proper pretreatment, a common practice in Mexico. The potential level of parasitological contamination of vegetables was estimated by analyzing bibliographic data collected under similar climatic and technological conditions as in Pachuca. Results indicate that the level of wastewater contamination from fecal coliforms in Pachuca was 5000 times higher than the maximum permissible level based on Mexican standards for irrigation waters, and for Áscaris lumbricoides L. and Hymenolepis diminuta (Rudolphi) eggs up to 64 times. The number of persons potentially infected through consumption of raw vegetables irrigated with this contaminated water was estimated to be 169,000 annually.
\end{abstract}

Keywords: helminth eggs, parasitological contamination of agricultural products, diseases

\section{Introduction}

Due to the insufficient availability of clean water for irrigation, sewage is being used by farmers in Mexico and several other countries as an alternate water source. The use of groundwater for agricultural purposes involves a high cost. Untreated urban, municipal and domestic wastewater contains high amounts of organic matter and nutrients such as phosphorus and nitrogen that can increase the yield of agricultural crops. Farmlands irrigated with this water annually receive an amount of organic matter approximately equal to the application of $100 \mathrm{t} / \mathrm{ha}$ of manure (SAGARPA, 2009). However, the wastewater also contains chemical and biological contaminants such as heavy metals, acids, oils, toxic chemicals, bacteria (mainly coliforms) and parasites (helminth eggs) that can contaminate soil, aquifers and agricultural products, which in turn, negatively impact human health. Unfortunately, growers and authorities underestimate or are unaware of the risks to public health associated with wastewater irrigation (Veliz et al., 2009).

In Mexico, the use of this water is regulated by Mexican standards (NOM001ECOL, 1996) and is only allowed for the irrigation of certain ornamental nursery crops, forage or grain, and should not be used to irrigate agricultural products used for direct human consumption such as vegetables which are often eaten raw. 
Each of these pollutants has its own effect on the quality of agricultural products, human health and on the soil. One of the parasites of special importance due to its high global incidence and in Mexico is Ascaris lumbricoides L. This nematode can cause irreversible damage to human health and often loss of life, especially in children (Rivas et al., 2003; Córdoba et al., 2010). In a study by Cifuentes et al. (1993) in Irrigation Districts 3 and 100 in the state of Hidalgo, 855 families were found to be irrigating with wastewater in various activities, a situation that led to a high degree of exposure to contaminated water; 930 families had an intermediate level of exposure. Human fecal samples were also collected to determine the presence of typical intestinal infections. The results showed the existence of parasites such as Ascaris lumbricoides, Giardia lamblia Kofoid and Christiansen, and Entamoeba histolytica Schaudinn. The risk of infection from A. lumbricoides was higher among children and adults, with children having the highest exposure, and experiencing greater risk of diarrhea and amebiasis.

Unfortunately, many farmers in Mexico do not know the negative impacts associated with the use of wastewater to irrigate their crops. State and local governments do not take strict measures to control the problem. The rural population generally has low income and low education, especially regarding health and ecological concepts, and is most affected by gastrointestinal diseases (especially among children). This is due to the consumption of raw agricultural products such as vegetables contaminated by the use of untreated sewage which is used for crop irrigation.

Mexico ranks first in the world in the use of untreated wastewater in agriculture (FAOSTAT, 2000; Garza, 2000). About an amount of 280,000 ha of agricultural land is irrigated annually in Mexico with untreated sewage (CNA, 2003). In Mexico there is no sanitary control of agricultural products, except for import or export.

It is known that untreated wastewater carries pathogenic bacteria, viruses and parasites (protozoa, helminths) which can negatively impact the quality of agricultural products, thus affecting human health (Rivas et al., 2003; Córdoba et al., 2010). Microbiological and parasitological analysis of wastewater shows that there is high contamination with pathogenic microorganisms, including helminths (Pérez-Cordón et al., 2008).

The objective of the present research study was to understand the process that involves the use of the sewage effluent from the city of Pachuca, in the state of Hidalgo, Mexico, due to its current use as irrigation water, and the potential harm to public health because the raw vegetables produced using this irrigation scheme are being consumed by the general public; as well as to determine the level of contamination in such wastewater, which is used for suburban agricultural irrigation (municipality of Pachuca). Also the parasitological contamination of vegetables irrigated with untreated wastewater was estimated as was their potential impact on human health. Our primary focus was directed at the presence of the nematode Ascaris lumbricoides in the irrigation water and vegetables, a parasite found in many studies, which is often more dangerous than other contaminants.

\section{Materials and Methods}

The municipality of Pachuca has 26,900 ha of seasonal agricultural land and 1,250 ha under irrigation, on which barley, oats, corn, maguey, cactus fruit and vegetables are planted. Around 170 ha are irrigated with untreated sewage from the city of Pachuca, of which about 80 ha produce vegetables for raw consumption, including lettuce, cilantro, parsley, spinach, radishes, carrots and onions (INEGI, 2013). Irrigation with untreated urban wastewater occurs primarily during relatively dry periods (October to April) receiving only $25 \%$ of the annual rainfall $(412 \mathrm{~mm})$. The average annual temperature is around $20^{\circ} \mathrm{C}$ with monthly temperatures varying between 18 and $25^{\circ} \mathrm{C}$. Altitude ranges between 2,400 and 2,600 mamsl (Figure 1). 


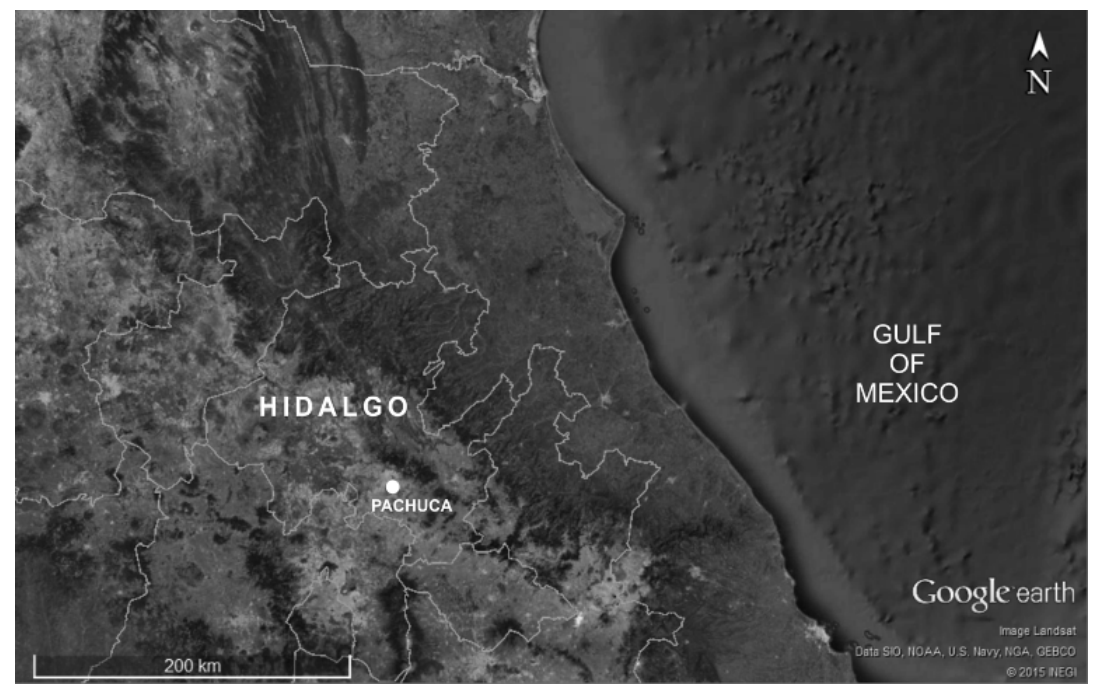

Figure 1. Location of the studied area

The research was conducted as follows:

1) Selection of wastewater sampling sites for the city of Pachuca.

2) Collection of untreated urban wastewater samples and determination of their physicochemical and parasitological contamination.

3) Estimation of contamination risk for raw vegetables irrigated with untreated urban wastewater.

4) Estimation of risks to human health as a result of consuming vegetables contaminated with helminth eggs.

To determine the quality of the untreated wastewater from the city of Pachuca, as recommended by city authorities, of the 6 existing emitters, the two having the highest discharge rate over 24 hours were selected and monitored: Río de Las Avenidas and Venado, which discharge more than $60 \%$ of untreated urban wastewater. Río de Las Avenidas is the largest in the city, while Venado produces less. All city emitters discharge their wastewaters into the "dry" streambeds, which exclusively receive this effluent during dry periods, but receive stormwater during wet periods. The network of these streams together with the network of irrigation canals conducts water to agricultural parcels for irrigation.

To determine physicochemical characteristics and parasitological contamination, water samples were collected from November 17-18, 2009 and from May 19-20, 2010 over 24 hours, with intervals of 2-3 hours according to Mexican national standard NOM001ECOL (1996). We used 500 plastic containers, 100 sterile bags, and acids ( $\mathrm{HCL}, \mathrm{H}_{2} \mathrm{SO}_{4}$ and $\mathrm{HNO}_{3}$ ) and $\mathrm{NaOH}$ to preserve the samples. Appropriate protective and hygienic measures were used during sample collection and handling, including latex gloves, face masks, goggles and boots. A 5 liter jug was used for sample collection, which had been previously washed with distilled water, and after filling it with wastewater it was stored in a cooler and transported to the Laboratorio de la Calidad del Agua (Water Quality Laboratory) at the Instituto Mexicano de Tecnología del Agua (Mexican Institute for Water Technology) in the city of Cuernavaca, Morelos, Mexico. Analytical protocols followed Mexican national standard NMX-AA-113-SCFI-1999.

Values for $\mathrm{pH}$, electrical conductivity (EC) and total solids (TS) of untreated urban wastewater were measured in the field using a multiparameter device (Hanna, 2009). Water temperature and flow were measured at each emitter discharge. To measure flow rate, a telescopic digital flow meter (model FP111, Global Water Flow Probe) was used.

To estimate the level of parasitological contamination (mainly from Ascaris lumbricoides) in vegetables irrigated with untreated wastewater from the city of Pachuca we used bibliographic data from other countries on such contaminants in certain types of vegetables irrigated with untreated wastewater, equal to the absence of sanitary control for agricultural products in Mexico. To analyze the bibliographic data on vegetable contamination, we took into consideration the type of urban water contamination at each site, comparing it to the wastewater quality from the city of Pachuca, including climatic conditions. 
To estimate the number of people potentially infected with A. lumbricoides due to consumption of raw vegetables grown on land irrigated with untreated wastewater from the city of Pachuca, we used the known quantity of vegetables produced annually from these areas (INEGI, 2009) and the consumption of raw vegetables per capita in Mexico (FAO, 2003). This number was compared with the figures published by INEGI (2009, 2013), although such figures are not entirely representative for our analysis because they do not distinguish types of intestinal diseases and they do not cover all cases.

\section{Results and Discussions}

Tables 1-4 show the results of analyses on the physicochemical quality, the content of heavy metals, fecal coliforms and helminth eggs in untreated wastewaters from the city of Pachuca. Permissible limits for irrigation water also are presented (De la Peña-De la Torre and Llerena-Villalpando, 2001).

Table 1. Physicochemical parameters of untreated wastewaters from the city of Pachuca

\begin{tabular}{|c|c|c|c|c|c|c|c|c|c|c|c|}
\hline Discharge & $\begin{array}{l}\text { Rate } \\
(\mathrm{L} / \mathrm{s})\end{array}$ & Year & $\mathrm{pH}$ & $\begin{array}{l}\text { EC } \\
(\mu S / m)\end{array}$ & $\begin{array}{l}\mathrm{BOD}_{5} \\
(\mathrm{mg} / \mathrm{L})\end{array}$ & $\begin{array}{l}\mathrm{COD} \\
\left(\mathrm{g} \mathrm{O}_{2} / \mathrm{L}\right)\end{array}$ & $\begin{array}{l}\mathrm{F} \text { and } \mathrm{O} \\
(\mathrm{mg} / \mathrm{L})\end{array}$ & $\begin{array}{l}\text { P-total } \\
(\mathrm{mg} / \mathrm{L})\end{array}$ & $\begin{array}{l}\text { TS } \\
(\mathrm{mg} / \mathrm{L})\end{array}$ & $\begin{array}{l}\text { Sediment } \\
(\mathrm{mL} / \mathrm{L})\end{array}$ & $\begin{array}{l}\text { N-total } \\
(\mathrm{mg} / \mathrm{L})\end{array}$ \\
\hline \multirow[t]{2}{*}{ Río las Avenidas } & 293 & 2009 & 6.7 & 1.6 & 177 & 415 & 114 & 6.74 & 112.00 & $<0.5$ & 40.70 \\
\hline & 287 & 2010 & 6.7 & 1.6 & 157 & 390 & 99.00 & 7.00 & 120.20 & $<0.5$ & 46.20 \\
\hline \multirow[t]{2}{*}{ Venado } & 45 & 2009 & 6.6 & 1.6 & 256 & 635 & 99.70 & 6.72 & 158.00 & $<0.5$ & 40.96 \\
\hline & 41 & 2010 & 6.6 & 1.6 & 210 & 580 & 84.35 & 6.00 & 132.10 & $<0.5$ & 49.08 \\
\hline \multicolumn{3}{|c|}{ Maximum permissible limits } & $5-7$ & $4 \times 10^{5}$ & 200 & 25 & 30 & 200 & 200 & 2 & 60 \\
\hline
\end{tabular}

Note. EC: Electrical conductivity; $\mathrm{BOD}_{5}$ : Biochemical oxygen demand; COD: Chemical oxygen demand; $\mathrm{F}$ and O: Fat and oils; P-Total: Total phosphorous; N-Total: Total nitrogen; TS: Total solids.

Table 2. Heavy metal content in untreated wastewaters from the city of Pachuca

\begin{tabular}{|c|c|c|c|c|c|c|c|c|c|c|}
\hline \multirow[b]{2}{*}{ Discharge } & \multirow[b]{2}{*}{ Year } & \multicolumn{9}{|c|}{ Heavy metal content $(\mathrm{mg} / \mathrm{L})$} \\
\hline & & $\begin{array}{l}\text { As } \\
(\mathrm{mg} / \mathrm{L})\end{array}$ & $\begin{array}{l}\mathrm{Cd} \\
(\mathrm{mg} / \mathrm{L})\end{array}$ & $\begin{array}{l}\mathrm{Cu} \\
(\mathrm{mg} / \mathrm{L})\end{array}$ & $\begin{array}{l}\mathrm{Cr} \\
(\mathrm{mg} / \mathrm{L})\end{array}$ & $\begin{array}{l}\mathrm{Hg} \\
(\mathrm{mg} / \mathrm{L})\end{array}$ & $\begin{array}{l}\mathrm{Ni} \\
(\mathrm{mg} / \mathrm{L})\end{array}$ & $\begin{array}{l}\mathrm{Pb} \\
(\mathrm{mg} / \mathrm{L})\end{array}$ & $\begin{array}{l}\mathrm{Zn} \\
(\mathrm{mg} / \mathrm{L})\end{array}$ & $\begin{array}{l}\text { Cyanides } \\
(\mathrm{mg} / \mathrm{L})\end{array}$ \\
\hline \multirow[t]{2}{*}{ Río las Avenidas } & 2009 & 0.023 & $<0.02$ & $<0.05$ & $<0.05$ & 0.0013 & 0.079 & 0.12 & 0.181 & $<0.020$ \\
\hline & 2010 & 0.049 & 0.031 & 0.06 & 0.053 & 0.002 & 0.077 & 0.12 & 0.869 & $<0.020$ \\
\hline \multirow[t]{2}{*}{ Venado } & 2009 & 0.015 & $<0.02$ & $<0.05$ & $<0.05$ & 0.001 & 0.058 & 0.111 & 0.22 & $<0.020$ \\
\hline & 2010 & 0.0203 & $<0.02$ & 0.005 & 0.07 & 0.0014 & 0.082 & 0.18 & 0.019 & $<0.020$ \\
\hline \multicolumn{2}{|c|}{ Maximum permissible limits } & 0.40 & 0.40 & 6.00 & 1.50 & 0.02 & 4.00 & 1.00 & 20.00 & 3.00 \\
\hline
\end{tabular}

Table 3. Fecal coliform content of untreated wastewaters from the city of Pachuca (Most Probable Number (NMP)/100 mL)

\begin{tabular}{lll}
\hline \multirow{2}{*}{ Discharge } & \multicolumn{2}{c}{ Fecal coliforms NMP/100mL (daily average) } \\
\cline { 2 - 3 } & November 2009 & May 2010 \\
\hline Río de la Avenidas & $5.26 \times 10^{6}$ & $4.26 \times 10^{6}$ \\
Venado & $1.20 \times 10^{6}$ & $1.20 \times 10^{6}$ \\
Maximum permissible limit & 1000 & \\
\hline
\end{tabular}


Table 4. Abundance of helminth eggs in untreated wastewaters from the city of Pachuca

\begin{tabular}{|c|c|c|c|c|c|}
\hline \multirow{2}{*}{ Discharge } & \multirow{2}{*}{ Helminth eggs species } & \multicolumn{2}{|c|}{ November 17, 2009} & \multicolumn{2}{|c|}{ May 19, 2010} \\
\hline & & No. Eggs/L & Total eggs & No. Eggs/L & Total eggs \\
\hline \multirow[t]{5}{*}{ Río de las Avenidas } & Hymenolepis diminuta (Rudolphi) & 33 & 64 & 23 & 42 \\
\hline & Ascaris lumbricoides & 18 & & 10 & \\
\hline & Trichuris spp. & 2 & & 1 & \\
\hline & Toxocara spp. & 2 & & 2 & \\
\hline & Hymenolepis nana (von Siebold) & 9 & & 6 & \\
\hline \multirow[t]{3}{*}{ Venado } & Hymenolepis diminuta & 2 & & 3 & 6 \\
\hline & Ascaris lumbricoides & 1 & 4 & 1 & \\
\hline & Trichuris spp. & 1 & & 2 & \\
\hline \multicolumn{2}{|c|}{$\begin{array}{l}\text { Maximum permissible limit for the total number of } \\
\text { helminth eggs in } 1 \mathrm{~L} \text { of water }\end{array}$} & & & & \\
\hline
\end{tabular}

As shown in Table 1, the physicochemical parameters are quite stable during the relatively dry periods and in different years, at least within the period of observation, and considering that sampling was conducted during different months: November 2009 and May 2010. The values for pH and EC are within permissible limits. The $\mathrm{BOD}_{5}, \mathrm{COD}$ and $(\mathrm{F}$ and $\mathrm{O}$ ) values exceed permissible limits for discharge into rivers and for irrigation use. The $\mathrm{COD}$ exceeds the permissible limit by 2 to 3 times. The content of fats and oils ( $\mathrm{F}$ and $\mathrm{O}$ ) exceeds the permissible limit by more than 4 times. This means that water quality has no direct impact on the quality of agricultural products, but has an indirect impact related to the deterioration of physical and biological soil properties and reducing soil fertility and productivity in lands irrigated with untreated urban wastewater. The fats and oils in the untreated urban wastewater used for irrigation caused soil particles to be hydrophobic, reduced soil moisture and microbial activities related with the humification of soil organic substances and the production of organic nitrogen during the process of mineralization of organic matter to produce humus. The gradual deterioration of soil quality leads to reduced productivity of agricultural land. This negative effect is seen over long periods of time (decades), while over shorter periods of time this effect cannot be observed due to the annual deposition of large amounts of organic material.

The heavy metal content is almost stable and well below permissible limits, indicating that there is no problem with contamination of soil and crops irrigated with untreated urban wastewater. However, because heavy metals are highly absorbed by soil particles, permitting little movement, over time (decades) such metals will gradually accumulate in soils, promoting the deterioration of microbial activities, reducing soil fertility and increasing their concentration in crops (Cajuste et al., 1991, 2001).

The fecal coliform content in the untreated urban wastewater exceeded the permissible limit for irrigation water by over a thousand times, which was expected, given that they are not subject to any treatment. This means that untreated urban wastewater will contaminate soil and vegetables, which will affect human health by causing different diseases when such products are consumed raw, without first washing and disinfecting them.

However, the negative effect on human health from vegetables contaminated with coliforms is significantly less compared to contamination with helminth eggs, which are more resistant to washing or other forms of treatment. Helminth egg concentration in untreated wastewater from the city of Pachuca exceeded the permissible limit for irrigation water by 64 times for the Río de las Avenidas discharge, and by 47 times, on average, for both discharge locations. The Río de las Avenidas discharge is the largest in the city, dumping more than $50 \%$ of all untreated urban wastewater. The wastewater from this emitter contains the highest concentration of helminth eggs. The most typical parasites from these untreated urban wastewaters are Hymenolepis diminuta (23-33 eggs/L), and Ascaris lumbricoides (10-18 eggs/L). There was no significant difference in the composition and concentration of different parasites between dry periods and major irrigation periods.

Thus, untreated urban wastewaters do not meet the standards for irrigation water and can heavily pollute the soil and vegetables, negatively affecting the health of people who consume these agricultural products without adequate prior treatment. Table 5 presents bibliographic data on the level of contamination of urban wastewaters and vegetables with helminth eggs in selected countries (Villanueva \& Silva, 1990; Muñoz \& Nancy, 2008; 
Hajjami et al., 2012; Valbuena, 2002; Rivera et al., 2009; Morais, 2005; Guzman et al., 2007; Rivera-Velázquez et al., 2007; Jiménez, 2009; Cifuentes et al., 1994).

Table 5. Parasitological contamination of untreated urban and municipal wastewaters and the vegetables irrigated with these waters in different countries

\begin{tabular}{|c|c|c|c|c|c|c|c|}
\hline Country & Location & Period & $\mathrm{T}\left({ }^{\circ} \mathrm{C}\right)$ & $\begin{array}{l}\text { Helminth eggs } \\
\text { in untreated } \\
\text { wastewater } \\
(\text { eggs/L) }\end{array}$ & $\begin{array}{l}\text { Contamination of } \\
\text { vegetables irrigated } \\
\text { with untreated } \\
\text { wastewater }\end{array}$ & Vegetables & Predominant species \\
\hline Iran & Isfahan, Teheran & $2002-2003$ & 23 & 21 & - & - & Ascaris spp. \\
\hline Pakistan & Faisalabad & & 22 & 142 & & & Ascaris spp. \\
\hline Peru & Cajamarca & Nov. to Dec. 2007 & 21 & - & 41 to 85 & $\begin{array}{l}\text { Parsley, } \\
\text { Lettuce }\end{array}$ & - \\
\hline Peru & Ica & 1990 & 22 & - & 73 to 165 & $\begin{array}{l}\text { Lettuce, Radish, } \\
\text { Scallions }\end{array}$ & Ascaris spp. \\
\hline Venezuela & Maracaibo, Zulia & Apr. 2002 & 30 & 183 & - & - & $\begin{array}{l}\text { Áscaris spp., } \\
\text { Ancylostomatoidea }\end{array}$ \\
\hline Brazil & Paraná & July 2002 to July 2007 & 17 to 20 & 100 & 114 to 181 & Lettuce Radish & Ancylostomatoidea \\
\hline Brazil & Porto Alegre & & $16-30$ & 31 & - & & \\
\hline Brazil & Itabira-MG & July 1997 to Apr. 1998 & 25 & 31 & - & - & Áscaris spp. \\
\hline Brazil & - & 2007 & & 100 & $\begin{array}{l}60 \text { helminth } \\
\text { eggs/plant }\end{array}$ & Lettuce & Áscaris spp. \\
\hline Bolivia & $\mathrm{LaPaz}$ & March 2004 to March 2006 & 10 to 22 & - & 405 to 477 & Onions, Lettuce & Áscaris spp. \\
\hline Morocco & Settat & June 2009 to Dec. 2010 & 22 & 9 & 84 to 100 & $\begin{array}{l}\text { Cilantro, Radish, } \\
\text { Parsley }\end{array}$ & Áscaris spp. \\
\hline Mexico & Texcoco & May 2004 to Apr. 2005 & 25 & 30 & - & - & Áscaris spp. \\
\hline Mexico & Tulancingo & 2009 & 18 to 20 & 9 to 24 & - & - & - \\
\hline Mexico & San Bernardino & June 2004 to Apr. 2005 & 21 & 8 & - & - & $\begin{array}{l}\text { Áscaris spp., } \\
\text { Hymenolepis nana }\end{array}$ \\
\hline
\end{tabular}

Note. $\mathrm{T}\left({ }^{\circ} \mathrm{C}\right)$ is the average temperature during the irrigation period.

As noted, there are few data on the parasitological contamination of vegetables irrigated with untreated urban wastewater, compared to aquatic contamination. According to Table 5, from 44-88\% of plants irrigated with untreated urban wastewater are contaminated with helminth eggs. Given the similarity in climatic conditions, type of parasitological contamination from untreated urban wastewater used for irrigation among the locations mentioned in Table 5 and the areas analyzed that use this form of irrigation in Mexico, there is a high risk of contamination of vegetables in the city of Pachuca. The primary type of parasitological contamination of vegetables in this municipality is from Hymenolepis diminuta and Ascaris lumbricoides and species of amoeba in the genus Entamoeba. It is an accepted standard that sanitary regulations do not allow the presence of helminth eggs in agricultural products.

To estimate the number of people potentially infected by helminths and Entamoeba as a result of consuming raw vegetables without proper treatment, we considered that agricultural land irrigated with untreated wastewater from the city of Pachuca annually yields about 3,600 t of raw vegetables, of which about $80 \%$ is sold in markets and the rest is lost (INEGI, 2009; Cruz, 2011; FAO, 2012; SIAP SAGARPA, 2013). In central Mexico, where the city of Pachuca is located, an average person consumes around $21.3 \mathrm{~kg}$ of vegetables each year (INEGI, 2009; FAO, 2003). Given the absence of sanitary control of agricultural products, contaminated vegetables are sold and consumed regularly. Thus, every year nearly 169,000 people may suffer infections primarily from Hymenolepis diminuta, Ascaris lumbricoides and Entamoeba.

INEGI $(2009 ; 2013)$ report that nearly 115,000 and 129,000 new cases of people with intestinal infections were recorded throughout the state of Hidalgo, respectively. Unfortunately, not all those infected are registered with 
medical services, and therefore are not included in INEGI statistics. In addition, the sources of infection reported by INEGI $(2009 ; 2013)$ are unclear as to whether they were derived from drinking water or consumption of foods such as meat or vegetables. Thus, comparing these data with the number of people potentially infected as a result of consuming raw vegetables contaminated by irrigation with untreated urban wastewater is not possible.

\section{Conclusions}

1) Untreated wastewater from the city of Pachuca, Hidalgo, Mexico, is not suitable for the irrigation of vegetables to be eaten raw by the human population.

2) The total abundance of helminth eggs in untreated urban wastewater exceeds the permitted limit by 64 times for Ascaris lumbricoides, and the fecal coliform limits are exceeded by more than 5000 times.

3) The physicochemical parameters $\mathrm{BOD}_{5}, \mathrm{COD}$ and ( $\mathrm{F}$ and $\mathrm{O}$ ) for untreated urban wastewaters exceeded the permissible limits for discharge to rivers and for irrigation use. The COD exceeds the allowable limit by 2 to 3 times. The content of fats and oils ( $\mathrm{F}$ and $\mathrm{O}$ ) exceeds the permissible limit by more than 4 times.

4) The estimated number of people potentially infected with Ascaris lumbricoides, Hymenolepis diminuta and Entamoeba spp. due to the consumption of contaminated raw vegetables without proper pretreatment is nearly 169,000 annually.

5) The risk of acquiring infection by Ascaris lumbricoides is high, especially in children who have a high exposure risk to untreated wastewaters used in agricultural irrigation.

\section{Acknowledgements}

To Consejo Nacional de Ciencia y Tecnología (CONACYT) and Colegio de Postgraduados, Campus Montecillo and Campus Veracruz for financial support.

\section{References}

Cajuste, L. J., Carrillo, G. R., Cota, G. E., \& Laird, R. J. (1991). The distribution of metals from wastewater in the Mexican Valley of Mezquital. Water, Air, and Soil Pollution, 57-58, 763-771. http://dx.doi.org/10.1007/BF00282940

Cajuste, L. J., Vázquez, A. A., Grabach, S. C. D., Alcántar, G. G., \& Isla, D. B. M. (2001). Cadmio, níquel y plomo en agua residual, suelo y cultivos en el Valle del Mezquital, Hidalgo, México. Agrociencia, 3(5), 267-274.

Cifuentes, E., Blumenthal, U. J., \& Ruiz-Palacios, G. (1994). Escenario epidemiológico del uso agrícola del agua residual: El Valle del Mezquital. Salud Pública México, 36(1), 3-9.

Cifuentes, E., Blumenthal, U., Ruíz-Palacios, G., Bennett, S., Quigley, M., Peasey, A., \& Romero-Avarez, H. (1993). Problemas de salud asociados al riego agrícola con agua residual en México. Salud Pública de México, 35(6), 614-619.

CNA [Comisión Nacional del Agua]. (2003). Estadísticas del Agua en México. Comisión Nacional del Agua, México, D.F.

Córdoba, M. A., Del Coco, V. F., \& Basualdo, J. A. (2010). Agua y salud humana. Química Viva, 9(3), 105-109.

Cruz, S. A. (2011). Se riegan con aguas negras $60 \%$ de cultivos agrícolas en Hidalgo (p. 32). La Jornada. México, D.F.

De La Pena-De La Torre, I., \& Llerena-Villalpando, F. A. (2001). Manual de Uso y Manejo de Agua de Riego. UACh-CONAGUA, México, D.F.

FAO. (2003). Perfiles Nutricionales por Países. México, FAO, Roma, Italy.

FAO. (2012). Pérdidas y Desperdicio de Alimentos en el Mundo-Alcance, Causas y Prevención. FAO, Roma.

FAOSTAT. (2000). Online Database. Retrieved June, 2014, from http://faostat.fao.org

Garza, A. V. (2000). Reuso agrícola de las aguas residuales de Cd. Juárez (Chih., México): En el valle de Juárez y su impacto en la salud pública. Revista Salud Pública y Nutrición, 1(3), 1-11.

Guzman, A., Palacios, O., Carrillo, R., Chavez, J., \& Nikolskii, I. (2007). La contaminación del agua superficial en la cuenca del río Texcoco, México. Agrociencia, 41(4), 385-393.

Hajjami, K., Ennaji, M. M., Fouad, S., Oubrim, N., \& Cohen, N. (2013). Wastewater Reuse for Irrigation in Morocco: Helminth Eggs Contamination's Level of Irrigated Crops and Sanitary Risk (A Case Study of Settat and Soualem Regions). Journal of Bacteriology \& Parasitology, 4(1), 163. 
http://dx.doi.org/10.4172/2155-9597.1000163

Hanna. (2009). Medidor Multiparametrico, Modelo HI991301. Retrieved from http://www.hannachile.com/prod uctos/multiparametro/multiparametros-portatiles/medidor-phectdstemperatura

INEGI. (2009). Anuario de Hidalgo 2009. Instituto Nacional de Estadística y Geografía, México, D.F. Retrieved from http://www.inegi.org.mx

INEGI. (2013). Anuario Estadístico y Geográfico del Estado de Hidalgo. Instituto Nacional de Estadística y Geografía, México, D.F. Retrieved from http://www.inegi.org.mx/prod_serv/contenidos/espanol/bvinegi/pro ductos/integracion/pais/anuario_multi/2013/hgo/AEyGHGO13.pdf

Jiménez, B. (2009). Helminth ova control in wastewater and sludge for agricultural reuse. In W. O. K. Grabow (Ed.), Encyclopedia of Biological, Physiological and Health Sciences, Water and Health (Vol. 2, pp. 429-449). UNESCO/EOLSS Publishers, Co. Ltd, Oxford. http://dx.doi.org/ 10.2166/wst.2007.555

MORAIS, F. L. (2005). Qualidades de hortalicas comercializadas em noroeste do Paraná, Brazil. Parasitología Latinoamericana, 60(3-4), 144-149. http://dx.doi.org/10.4067/S0717-77122005000200007

Muñoz, O. V., \& Nancy, L. (2008). Alta contaminación por enteroparasitos de hortalizas comercializadas en los mercados de la ciudad de la Paz, Bolivia. Biofarbo, 16(1), 1-8.

NMX-AA-113-SCFI. (1999). Análisis de Agua-Medición del Número de Huevos de Helminto en Aguas Residuales y Residuales Tratadas por Observación Microscópica-Método de Prueba. México, D.F.

NOM001ECOL. (1996). Norma Oficial Mexicana que establece los límites máximos permisibles de contaminantes en las descargas de aguas residuales en aguas y bienes nacionales. Diario Oficial de la Federación. México, D.F.

Pérez-Cordón, G., Rosales, M. J., Renzo, V. A., Vargas-Vásquez, E., \& Córdova, O. (2008). Detección de parásitos intestinales en agua y alimentos de Trujillo, Perú. Revista Peruana de Medicina Experimental y Salud Pública, 25(1), 144-148.

Rivas, L. B. A., Nevarez, M. G. V., Bautista, M. R. G., Perez, H. A., \& Saucedo, T. R. (2003). Tratamiento de aguas residuales de uso agrícola en un bioreactor de lecho fijo. Agrociencia, 37(2), 157-166.

Rivera, J. A., Rodriguez, U. C. A., \& Lopez, O. (2009). Contaminación fecal en hortalizas que se expenden en mercados de la ciudad de Cajamarca, Perú. Revista Peruana de Medicina Experimental y Salud Publica, $29(1), 45-48$.

Rivera-Vázquez, R., Palacios-Vélez, O. L., Chávez-Morales, J., Belmont, M. A., Nikolski-Gavrilov, I., De La Isla De Bauer, Ma. L., ... Carrillo-Gonzalez, R. (2007). Contaminación por coliformes y helmintos en los ríos Texcoco, Chapingo y San Bernardino tributarios de la parte oriental de la Cuenca del Valle de México. Revista Internacional de Contaminación Ambiental, 23(2), 69-77.

SAGARPA. (2009). Tipos de Abonos Orgánicos de Origen Animal y su Composición Química. Retrieved from http://plantasyhortalizas.blogspot.mx/2009/08/tipos-de-abonos-organicos-de-origen.html

SIAP SAGARPA. (2013). Producción Agropecuaria en México. Datos Estadísticos, SAGARPA. México, D.F.

Valbuena, D., Diaz-Suarez, O., Botero-Ledesma, L., \& Cheng-Ng, R. (2002). Detección de helmintos intestinales y bacterias indicadoras de contaminación en aguas residuales, tratadas y no tratadas. INCI, 27(12), 710-714.

Veliz, L. E., Llanes, O. J. G., Asela, F. L., \& Bataller, V. M. (2009). Reuso de aguas residuales domesticas para riego agrícola. Valoración crítica. Revista CENIC, Ciencias Bilógicas, 40(1), 35-44.

Villanueva, R. C., \& Silva, S. M. (1998). Protozoarios y helmintos en hortalizas comestibles que se expenden en los mercados de la ciudad de Ica. Revista peruana de Parasitología, 13(1), 84-89.

\section{Copyrights}

Copyright for this article is retained by the author(s), with first publication rights granted to the journal.

This is an open-access article distributed under the terms and conditions of the Creative Commons Attribution license (http://creativecommons.org/licenses/by/3.0/). 